\title{
RU 486 completely inhibits the action of progesterone on cell proliferation in the mouse uterus*
}

\author{
T. E. Cullingford and J. W. Pollard* \\ MRC Group in Human Genetic Diseases, Department of Biochemistry, King's College, \\ Campden Hill, London W8 7 AH, U.K.
}

\begin{abstract}
Summary. The antiprogestagen RU 486 completely inhibited the progesterone-induced switch in cell proliferation from the luminal and glandular epithelia to the stroma in response to oestradiol-17 $\beta$. It also inhibited the progesterone-induced differentiation of the uterine epithelium. Since the proliferative switch of the uterus and the differentiation of the epithelium are prerequisites for implantation, these inhibitory actions may, in part, explain the ability of RU 486 to prevent implantation. Furthermore, it also suggests that the proliferative response to oestradiol in the presence of progesterone may be a sensitive assay for compounds with anti-progestational activity.
\end{abstract}

Keywords: oestrogen; progesterone; RU 486; uterus; cell proliferation; mouse

\section{Introduction}

In the uterus of the adult mouse oestradiol-17 $\beta$ causes a synchronized wave of epithelial cell proliferation (Martin et al., 1973a, 1976). Pre-treatment with progesterone for 3 days (Martin et al., 1973b) completely inhibits this epithelial proliferation and sensitizes the stromal cells to respond to oestradiol with a wave of cell division. This proliferative switch is diagnostic for progestational agents and is an essential prerequisite for successful implantation. The proliferative switch might act as a single-point assay for antiprogestational agents. Such agents would not only provide tools for studying progesterone action but would also be effective contraceptives and useful in the management of endocrine-responsive tumours.

RU 486 is an antiprogestagen which also has some anti-glucocorticoid activity (Philibert et al., 1985). It binds with high affinity to the progesterone receptor (Rauch et al., 1985) and in in-vitro assays this RU 486-receptor complex binds to the correct regions of steroid-responsive genes (Bailly et al., 1986). It therefore acts by sequestering the progesterone receptor in a form which is bound to the DNA but unable to stimulate transcription. It is effective in blocking implantation and decidualization in rats (Philibert et al., 1985; Psychoyos \& Prapas, 1987), inducing abortion in humans (Baulieu, 1985) and in preventing the progesterone regulated synthesis of uterine growth factors (Pollard et al., 1987). This study was performed to test whether RU 486 was able to inhibit the progesterone-induced redirection of cell proliferation from the luminal and glandular epithelium to the stroma in the mouse uterus.

\section{Materials and Methods}

Adult Schneider mice ( $\sim 30 \mathrm{~g}$ ) were ovariectomized and primed with oestrogen as described by Cheng et al. (1985). At 2 days after priming groups of mice were placed on one of the following injection regimens given subcutaneously in arachis oil: (1) treated with carrier alone for 4 days; (2) given a single dose of $50 \mathrm{ng}$ oestradiol-17 $\beta$ on the 4 th day; (3)

\footnotetext{
* Reprint requests to Dr J. W. Pollard.
} 
given $500 \mu \mathrm{g}$ progesterone daily for 4 days, and (4) as for (3) but with $50 \mathrm{ng}$ oestradiol-17 $\beta$ on the 4 th day. RU 486 was given alone in $500 \mu \mathrm{g}$ daily injections for 4 days, or starting 2 days after priming for 4 days concurrently with regimens (2), (3) or (4). RU 486 was prepared by dissolving it in a small volume of alcohol, making it up to the required concentration in arachis oil and heating to $60^{\circ} \mathrm{C}$ for $15 \mathrm{~min}$.

The proliferative activity of the luminal epithelial cells was determined by the level of incorporation of $\left[{ }^{3} \mathrm{H}\right]$ thymidine. Five uterine horns from mice killed at appropriate times after the hormone treatments described above were incubated in $1 \mathrm{ml} \alpha$-minimal essential medium lacking deoxyribonucleosides and ribonucleosides and containing $10 \%$ $(\mathrm{v} / \mathrm{v})$ fetal calf serum and $10 \mu \mathrm{Ci}$ methyl $\left[1,2-{ }^{3} \mathrm{H}\right]$ thymidine (sp. act. $113 \mathrm{Ci} / \mathrm{mmol}$ : Amersham Radiochemicals, Amersham, Bucks, U.K.) for 1 h. After incubation the luminal epithelium was removed by the method of Fagg et al. (1979) and the radioactive incorporation into acid-precipitable material was determined as described by Cheng et al. (1985). The DNA content of the epithelial homogenate was measured by either Burton's reaction (Burton, 1956) or the diaminobenzoic acid method (Hinegardner, 197I). This assay would be sensitive enough to detect a $25 \%$ restoration, by an anti-progestagen, of the luminal epithelial DNA synthetic response induced by oestradiol, in animals treated with progesterone and oestradiol. To determine the proliferative activity of the whole uterus, colchicine-arrested mitotic figures were counted in groups of 3 animals killed $24 \mathrm{~h}$ after the last hormone treatment as described by Martin et al. (1973a). At autopsy all uteri were fixed in Bouin's fluid, embedded in paraffin wax, sectioned transversely at $5 \mu \mathrm{m}$ and stained in Cole's haematoxylin and eosin (Martin et al., 1973a). The mitotic index of a random section of the mid portion of each uterine horn was determined by counting every luminal and glandular epithelial cell and a representative section through the stroma either side of the uterine lumen. Counts from each pair of uterine horns were pooled and the mean of the groups determined and expressed as the percentage mitosis. All groups were compared by using Student's $t$ test.

\section{Results}

Oestradiol treatment of ovariectomized animals caused a synchronized wave of luminal DNA synthesis as determined by $\left[{ }^{3} \mathrm{H}\right]$ thymidine incorporation. This elevated rate began $6 \mathrm{~h}$ after administration and peaked at $12-15 \mathrm{~h}$ (Fig. 1). The wave of $\left[{ }^{3} \mathrm{H}\right]$ thymidine incorporation was associated with an increased mitotic index in both the luminal and glandular epithelia at $24 \mathrm{~h}$ showing that the cells had been stimulated to proliferate (Fig. 2b, Table 1). Treatment with progesterone for 4 days resulted in a characteristic epithelial morphology with increased subnuclear vacuolation, regularly aligned shrunken nuclei, pale cytoplasm and a corrugated luminal surface (Figs 2c, d). This treatment also completely suppressed the oestradiol-induced epithelial proliferative response (Figs 1, 2d; Table 1) but, in turn, sensitized the stroma to respond to oestradiol with an increased mitotic index $24 \mathrm{~h}$ after injection (Table 1, Fig. 2d). Thymidine incorporation was not determined in the stroma since, unlike the luminal epithelium, this tissue cannot

Table 1. Effect of RU 486 on the progesterone-induced switch of proliferation in response to oestradiol-17 $\beta$ from the epithelium to the stroma in the mouse uterus

\begin{tabular}{|c|c|c|c|}
\hline \multirow[b]{3}{*}{ Hormone treatment } & \multicolumn{3}{|c|}{ Mitotic index $(\%)$} \\
\hline & \multicolumn{2}{|c|}{ Epithelium } & \multirow[b]{2}{*}{ Stroma } \\
\hline & Luminal & Glandular & \\
\hline No treatment & $0.7 \pm 0.4$ & $0.7 \pm 0.2$ & $0 \cdot 0$ \\
\hline RU 486 alone & $0.7 \pm 0.1$ & $0 \cdot 7 \pm 0.3$ & $0 \cdot 0$ \\
\hline Progesterone alone & $0 \cdot 0$ & $0 \cdot 0$ & $0 \cdot 2 \pm 0 \cdot 1$ \\
\hline Oestradiol alone & $3 \cdot 0 \pm 0 \cdot 6^{*}$ & $3 \cdot 4 \pm 0 \cdot 2^{*}$ & $0 \cdot 0^{*}$ \\
\hline Progesterone + oestradiol & $0 \cdot 0$ & $0 \cdot 1 \pm 0 \cdot 1$ & $2 \cdot 6 \pm 0.4$ \\
\hline RU 486 + progesterone + oestradiol & $7 \cdot 6 \pm 0.4^{*}$ & $5.2 \pm 0.7^{*}$ & $0 \cdot 1 \pm 0 \cdot 1^{*} \dagger$ \\
\hline
\end{tabular}

Values are mean \pm s.e.m. of three pairs of uterine horns.

${ }^{*} P<0.001$ compared with the value for the comparable group of animals treated with progesterone and oestradiol-17 $\beta$.

†One uterus had mitotic figures situated at the outer edge of the glands which were probably glandular mitotic but figures were scored as stromal mitotic figures. 


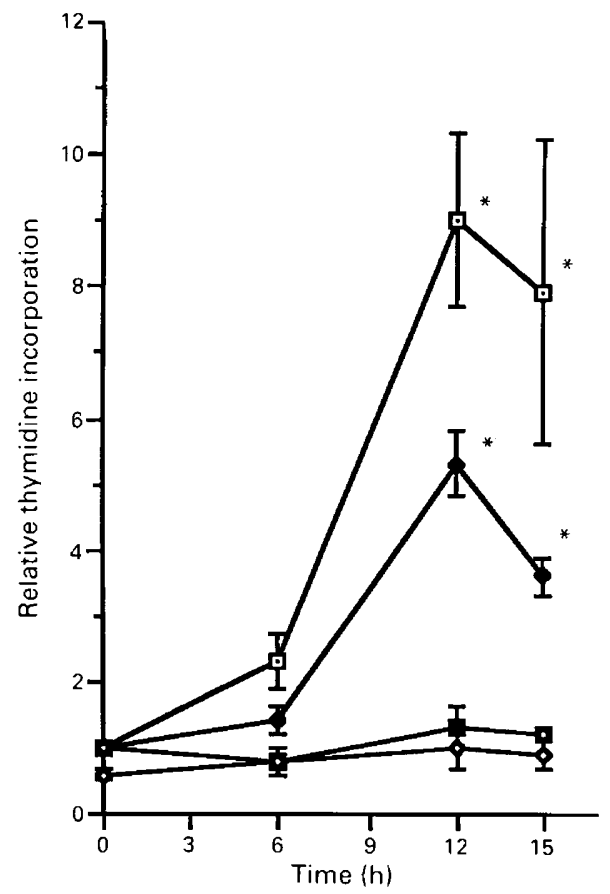

Fig. 1. A time course of the effect of oestradiol-17 $\beta$-induced $\left[{ }^{3} \mathrm{H}\right]$ thymidine incorporation into mouse uterine luminal epithelial cells. Ovariectomized animals were treated for 4 days with arachis oil $(\square) ; 500 \mu \mathrm{g}$ progesterone $(\diamond)$ or $500 \mu \mathrm{g}$ RU $486+500 \mu \mathrm{g}$ progesterone $(\diamond)$. At zero time they were given $50 \mathrm{ng}$ oestradiol and the incorporation of $\left[{ }^{3} \mathrm{H}\right]$ thymidine into acidinsoluble material was estimated at various times thereafter as described in 'Materials and Methods'. To another group, $500 \mu \mathrm{g}$ RU 486 were administered for 4 days ( $\boldsymbol{\square}$ ). Because of the day-to-day variations of the rate of incorporation into the vehicle-treated controls, values for each group were normalized to the appropriate daily control group and expressed as a relative stimulation over this control (ordinate). Each point represents a mean \pm s.e.m. of at least 2 sets of duplicate groups of 5 uterine horns performed on different days. ${ }^{*} P<0.001$ compared to their controls and the equivalent group given progesterone and oestradiol.

be obtained with any degree of purity and is heavily contaminated with glandular epithelial cells.

RU 486 on its own had no effect on DNA synthetic rate (Fig. 1) or on the mitotic index (Fig. 2e, Table 1) and the uteri were indistinguishable from the control group (Fig. 2a, e). Given together with oestradiol it did not have a significant effect on the stimulation of DNA synthesis in the luminal epithelium (data not shown), showing that it had no agonist activity. Given with progesterone, however, RU 486 inhibited the suppression of the luminal epithelial DNA synthetic response to oestradiol and resulted in a return to the induced wave of DNA synthesis beginning at $6 \mathrm{~h}$ and peaking at $12 \mathrm{~h}$ (Fig. 1). The pattern of mitosis was also restored to the oestradiol type, with substantial numbers of mitotic figures being observed in the luminal and glandular epithelia with none in the stroma (Fig. 2f; Table 1). Although the level of DNA synthesis in the luminal epithelium in RU 486-treated mice was significantly lower $(P<0.05)$ at $12 \mathrm{~h}$ than in the group given oestradiol treatment alone (Fig. 1), the numbers of mitotic figures were significantly increased $(P<0.001)$ at $24 \mathrm{~h}$ in this tissue. This suggests either a lower specific activity of the thymidine pool or a slight sampling effect. In either case, taking the data together, RU 486 completely restored the epithelial proliferative response to the level observed after oestradiol treatment alone. RU 486 also 

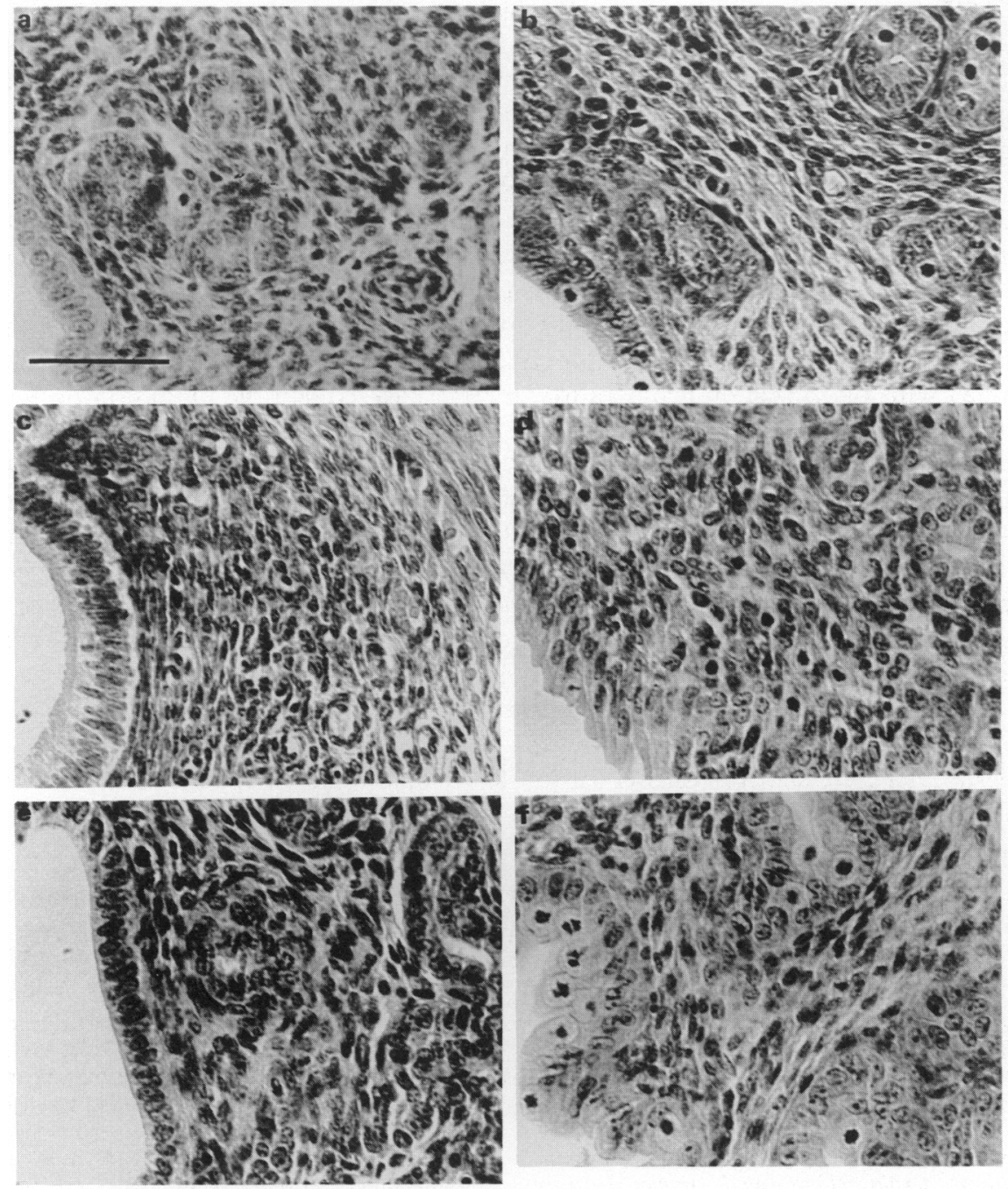

Fig. 2. Transverse sections of mouse uteri displaying colchicine-arrested mitosis. All animals were given $100 \mu \mathrm{g}$ colchicine intraperitoneally $2 \mathrm{~h}$ before being killed $24 \mathrm{~h}$ after the last treatment: (a) arachis oil alone for 4 days; (b) as in (a), except that 50 ng oestradiol were given on the last day: mitotic figures are localized only in the luminal and glandular epithelia; (c) $500 \mu \mathrm{g}$ progesterone for 4 days: the epithelium has a characteristically lightly stained cytoplasm, aligned shrunken nuclei and corrugated cell surface; (d) as in (c), except that 50 ng oestradiol were given on the last day; the mitotic figures are now confined to the stroma, principally in the periplasmic area, with none in the luminal or glandular epithelium; (e) $500 \mu \mathrm{g}$ RU 486 for 4 days; and (f) $500 \mu \mathrm{g}$ RU 486 combined with $500 \mu \mathrm{g}$ progesterone for 4 days with $50 \mathrm{ng}$ oestradiol given on the 4th day. The mitotic figures are confined to the luminal and glandular epithelium, similar in pattern to (a). Bar $=50 \mu \mathrm{m}$.

reversed the characteristic epithelial differentiation produced by progesterone (Fig. 2f) and produced a morphology similar to that of uteri from mice given oestradiol alone. It also suppressed the progesterone sensitization of the stroma such that no stromal mitosis occurred in response to oestradiol treatment (Table 1). 


\section{Discussion}

The proliferative effect of oestradiol and its modulation by progesterone observed in these experiments were essentially as described by Martin et al. (1973a, b, 1976). In the rabbit, however, progesterone stimulates rather than suppresses epithelial cell division (Lee \& Dukelow, 1972), an effect which is completely inhibited by RU 486 (Philibert et al., 1985). In mice and rats the progesterone-induced proliferative switch is essential for implantation (Finn \& Martin, 1967, 1969). In the present studies, RU 486 was an effective anti-progestagen since it reversed the suppression of the oestradiol-induced luminal epithelial DNA synthesis by progesterone and prevented the progesterone sensitization of the stroma to respond to oestradiol with cell proliferation. Furthermore, it also inhibited the progesterone-induced differentiation of the epithelium. This, coupled with the effects on proliferation, may in part explain the inhibition by RU 486 of implantation.

RU 486 appears to act by high affinity binding to the progesterone receptor, trapping it into an inactive DNA-receptor complex (Rauch et al., 1985; Bailly et al., 1986). RU 486 and progesterone are structurally dissimilar (Baulieu, 1985), suggesting that they are unlikely to have common nonreceptor-mediated effects. The data on the inhibitory action by RU 486 therefore strongly suggest that the proliferative effects of progesterone are mediated via its receptor. The efficacy of RU 486 also suggests that the progesterone-induced switch of proliferation in response to oestradiol, determined by colchicine-arrested mitosis or by $\left[{ }^{3} \mathrm{H}\right]$ thymidine incorporation, provides an easy, sensitive, single-point assay for compounds with anti-progestational activity.

We thank Dr R. Deraedt of Roussel for the RU 486; and Dr G. Jones and J. Pacey for help with photography. This work was supported by grants from the MRC U.K. and by an SERC postgraduate research studentship to T.C.

\section{References}

Bailly, A., Le Plage, C., Rauch, M. \& Milgrom, E. (1986) Sequence specific DNA binding of the progesterone receptor to the uteroglobin gene: effects of hormone, antihormone and receptor phosphorylation. $E M B O$ J. 5, 3235-3241.

Baulieu, E.E. (1985) RU 486: an antiprogestagen steroid with contragestive activity in women. In The Antiprogestagen Steroid RU 486 and Human Fertility Control, pp. 1-25 Eds E. E. Baulieu \& S. J. Segal. Plenum Press, New York.

Burton, K. (1956) A study of the condition and mechanism of the diphenylamine reaction for the colorimetric estimation of deoxyribonucleic acid. Biochem. J. 62, 31 5-323.

Cheng, S.V.Y., MacDonald, B.S., Clark, B.F. \& Pollard, J.W. (1985) Cell growth and cell proliferation may be dissociated in the mouse uterine luminal epithelium treated with female sex steroids. Expl Cell Res. 160, $459-470$,

Fagg, B., Martin, L., Rogers, L.A., Clark, B.F. \& Quarmby, V.E. (1979) A simple method for removing the luminal epithelium of the mouse uterus for biochemical studies. J. Reprod. Fert. 57, 335-339.

Finn, C.A. \& Martin, L. (1967) Patterns of cell division in the mouse uterus during early pregnancy. J. Endocr. 39, 593-597.

Finn, C.A. \& Martin, L. (1969) Hormone secretion during early pregnancy in the mouse. J. Endocr. 45, $57-65$.
Hinegardner, R.T. (1971) An improved fluorometric assay for DNA. Analyt. Biochem. 39, 197-201.

Lee, A.E. \& Dukelow, W.R. (1972) DNA synthesis and mitosis in rabbit uteri after estrogen and progesterone injections and during early pregnancy. $J$. Reprod. Fert. 31, 473-476.

Martin, L., Finn, C.A. \& Trinder, G. (1973a) Hypertrophy and hyperplasia in the mouse uterus after estrogen treatment: an autoradiographic study. $J$ Endocr. 56, 133-144.

Martin, L., Finn, C.A. \& Trinder, G. (1973b) DNA synthesis in the endometrium of progesterone treated mice. J. Endocr. 56, 303-307.

Martin, L., Pollard, J.W. \& Fagg, B. (1976) Oestriol, oestradiol-17 $\beta$ and the proliferation and death of uterine cells. J. Endocr. 69, 103-115.

Philibert, D., Moguilewsky, M., Mary, I., Lecaque, D., Tournemine, C., Secchi, J. \& Deraedt, R. (1985) Pharmacological profile of RU 486 in animals. In The Antiprogestin Steroid RU 486 and Human Fertility Control, pp. 49-68. Eds E. E. Baulieu \& S. J. Segal Plenum Publishing Corp., New York.

Pollard, J.W., Bartocci, A., Arceci, R., Orlofsky, A., Ladner, M.B. \& Stanley, E.R. (1987) Apparent role of the macrophage growth factor CSF-1 in placental development. Nature, Lond. 330 , $484-486$

Psychoyos, A. \& Prapas, I. (1987) Inhibition of egg development and implantation in rats after post coital 
administration of the progesterone antagonist RU 486. J. Reprod. Fert. 80, 487-491.

Rauch, M., Loosfelt, H., Philibert, D. \& Milgrom, E. (1985) Mechanism of action of an antiprogesterone, RU 486, in the rabbit endometrium. Effects of
RU 486 on the progesterone receptor and on the expression of the uteroglobin gene. Eur. J. Biochem. 148, 213-218.

Received 25 January 1988 